\title{
DEVELOPMENT AND EVALUATION OF TARGETED MARGINAL LAND MAPPING APPROACH IN SWAT MODEL FOR Simulating WATER QUALity IMPaCtS OF SELECTED SECOND GENERATION BIOFEEDSTOCK
}

\author{
Gurdeep Singh $^{a}$ and Dharmendra Saraswat ${ }^{b \text {,* }}$
}

\begin{abstract}
${ }^{\mathrm{a}}$ Graduate Student, Department of Biological and Agricultural Engineering, University of Arkansas, Fayetteville, Arkansas, U.S.A.

${ }^{\mathrm{b}}$ Associate Professor, Department of Agricultural and Biological Engineering, Purdue University, West Lafayette, IN, U.S.A. *Corresponding author: Dharmendra Saraswat, 225, S. University Street, West Lafayette, IN 47907; Phone: $\underline{765-494-5013}$; email: saraswat@purdue.edu.
\end{abstract}

ABSTRACT. Information about location of marginal lands in a watershed is of interest to those who view these areas as potential land for producing biofuel crops. However, representing marginal lands into a distributed model such as the Soil and Water Assessment Tool (SWAT) is a challenge due to a rigid framework used for watershed sub-division. In this study, we developed a Geographic Information System (GIS) based approach for implementing targeted land use i.e. marginal lands into the SWAT model and evaluated the applicability of the approach on a 8digit Hydrologic Unit Code (HUC) watershed scale. Comparative results showed that conventional targeting approach overestimates the benefit of targeting marginal lands for Alamo switchgrass (Panicum virgatum, L) and $g$ miscanthus (Miscanthus x giganteus) production due to simulation of larger area under marginal land category. Compared to baseline condition, which corresponds to no biofuel crop production on marginal lands, the pollutant losses under new targeting approach with simulation of Alamo switchgrass and giant miscanthus on marginal lands were substantially lower. The new targeting approach advances the science behind landscape representation in the SWAT model - that has potential to be used in future targeting studies.

Keywords. Targeting, marginal land, SWAT, biofuel crops, water quality

\section{INTRODUCTION}

The Renewable Fuel Standard (RFS) program under the Energy Policy Act (EPAct) of 2005 mandated 28 billion liters (7.5 billion gallons) of renewable fuel to be blended into gasoline by 2012 (EPA, 2012). The Energy Independence and Security Act (EISA) of 2007 expanded the RFS program by increasing the volume of renewable fuel required to be blended into transportation fuel to 136 billion liters (36 billion gallons) by 2022 (EISA, 2007). Under the EISA (2007) Act, corn starch and cellulosic biofuels were identified as major renewable fuel sources. 
Corn starch falls under the category of first generation biofuel crops along with soybean [Glycine max (L.) Merr.], cotton (Gossypium hirsutum), and some other row crops. Studies have reported eutrophication problems relating with the first generation biofuel crop productions (Babcock et al., 2007; Donner and Kucharik, 2008; Powers, 2007). Increased uses of corn (Zea mays L.) and soybeans have been reported to worsen eutrophication problems in Midwest US and Gulf of Mexico (Powers, 2007). As per the EISA (2007) Act, fuel requirement from corn starch ethanol is not expected to increase beyond 56 billion liters (15 billion gallons) in 2015. Because of the fact that increasing area under first generation biofuel crops has the potential to exacerbate eutrophication problems as reported by other researchers and oil requirement from corn starch is projected to plateau in 2015 , the research community has focused attention on second generation biofuel crops.

Second-generation biofuel crops also known as cellulosic biofuels include dedicated energy crops (e.g. switchgrass and miscanthus) that are grown exclusively for fuel production. The EISA (2007) Act mandated a target volume of 60 billion liters (16 billion gallons) for second-generation biofuel crops. To meet targeted volume, three production strategies are recognized: displacement, intensification and expansion/targeting approach (Kloverpris et al., 2008). Displacement involves cultivation of field for biofuel production on current land uses. However, this strategy might result in the food vs. fuel debate. The second strategy, intensification, involves increase in biofuel crop yield with increase in inputs like fertilizer application, pesticide application, irrigation level, and the cropping intensity. However, the increase in yield per unit of input is often subjected to diminishing returns (Kloverpris et al., 2008). The third strategy, expansion/targeting, involves the conversion of targeted area (e.g. marginal or degraded land) to biofuel crop production.

It is pertinent to note that a report suggested an annual production of 30 billion liters ( 8 billion gallons) of advanced biofuels i.e. half of targeted production under EISA Act of 2007, might result from dedicating $10 \%$ of marginal lands along the Missouri and Mississippi rivers to energy crop production (Geiver, 2012). However, the definition of marginal land is not constant and it varies widely as per country, local conditions and the organizations studying the issue (Dale et al., 2010). The same attributes that qualify a land as marginal in one place or for one purpose might regard it productive in another place or for another purpose (Dale et al., 2010). Similarly, marginal lands could be defined using a single (Strijker, 2005) or multiple biophysical variables (Gopalakrishnan et al., 2011). Strijker (2005) defined marginal land as land with marginal economic viability whereas Gopalakrishnan et al. (2011) defined it based on soil health, current land use, and environmental degradation. Irrespective of the definition, marginal or degraded land has been reported as an environmentally friendly and sustainable approach for producing second-generation biofuel crops production (Campbell et al., 2008; Kort et al., 1998).

Estimating environmental benefits of biofuel crop production has frequently relied on the use of hydrologic and water quality (H/WQ) watershed models. These models help in predicting sediment and nutrient loss under various land uses, management, and climate conditions (Singh and Frevert, 2006). Among several H/WQ models, the SWAT model has been used by numerous studies for simulating biofuel crop production. For example, SWAT was used for assessing regional water quality implication of biofuel feedstock production in Upper Mississippi River Basin (Demissie et al., 2014). Sarkar and Miller (2014) used SWAT to model nitrogen losses from simulated switchgrass at the watershed scale. Apart from bioenergy crops simulation, the SWAT model has also been applied 
to identify critical source areas (CSA) for effective targeting of areas. Niraula et al. (2012) identified sediment and nutrient CSAs and concluded that the calibration process should not affect the CSAs. Panagopoulos et al. (2011) parametrized SWAT for identifying CSAs under data limitations and concluded that the CSAs of sediments and nutrients can be identified with the current data limitations. Winchell et al. (2014) identified phosphorus CSAs by adjusting SCS curve numbers based on local compound topographic index and reported that $20 \%$ of the watershed produced $74 \%$ of the total phosphorus (TP) load.

Our group has been active in researching issues related to identifying CSAs. CSAs can be identified at the subwatershed (Pai et al., 2011) and hydrological response unit (HRU) (Pai et al., 2012) level. Targeting work at the HRU level resulted in the development of tools such as SWAT2009_LUC and FIELD_SWAT (Pai and Saraswat, 2011; Pai et al., 2012). The SWAT2009_LUC tool updates land uses over the modeling period by redistributing HRU fractions in subwatersheds. Updating land use represents a more realistic temporal land use variation in models for heterogeneous watersheds. Moreover, the updated version of SWAT2009_LUC tool includes a feature to analyze the impact of land use categorical uncertainty on SWAT hydrologic modeling (Pai and Saraswat, 2013). The FIELD_SWAT tool converts HRU level outputs to the field boundaries defined by the user. The present study advances our group's targeting related work at the HRU level. Apart from our group, White et al. (2009) used SWAT to identify and quantify sediment and TP loads originating from CSAs. White et al. (2009) considered six Oklahoma priority watersheds from 2001 to 2007. Sediment and TP loads were obtained from each HRU. The HRUs were ranked as per the predicted sediment and TP loadings, and the highest 2.5 and $5 \%$ fractions were defined as CSAs. Ghebremichael et al. (2010) conducted a similar study identifying CSAs for phosphorus loss in the Rock River watershed, Vermont. They selected SWAT predictions on an HRU level in determining CSAs of phosphorus loss. Currently, there is a growing interest among researchers in conducting SWAT related HRU level studies (Huang et al., 2015; Her et al., 2015).

HRUs are the lowest simulation level in SWAT with specific identification numbers (IDs). However, HRUs are discontinuous landmasses in a subwatershed (Gassman et al., 2007; Pai et al., 2012), thereby posing a challenge in simulating targeted crop production in a spatially distributed manner. For example, assume that there is a typical model setup containing a rectangular subwatershed with four quadrants that represents the arrangement of HRUs (Fig. 1a). Further, assume that the marginal land (or the targeted area) is located in the first quadrant (Fig. 1b). Therefore, quadrant no. 1 should only be the focus of simulation in order to simulate crop production on marginal lands. However, as per the conventional model setup, crops simulated on HRU no. 1 will also be simulated in the fourth quadrant (along with the first quadrant) because of the presence of the same HRU in the fourth quadrant of the subwatershed. Thus, spatial discontinuity among HRUs hinders the simulation of crop production on spatially delineated marginal lands. As a result, there is a need to develop a new approach for simulating crops on those HRUs only that represents marginal lands for their accurate spatial representation in the watershed. 
(a)

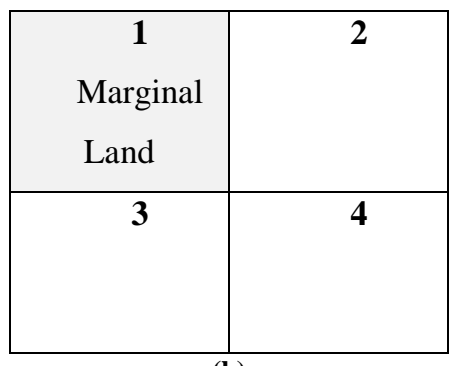

(b)

Fig. 1. (a) Hypothetical distribution of hydrological response units in a subwatershed and (b) Hypothetical location of marginal land in a subwatershed.

The objective of this study was to develop a new targeted land use simulation approach in SWAT model and assess comparative performance of conventional and new targeting approach for evaluating water quality impacts of second generation biofeedstocks produced on marginal lands. The tasks associated to accomplish study objective were: (1) development of a new simulation approach for incorporating marginal land in the SWAT model developed for L'Anguille River watershed (LRW), (2) setting up a conventional SWAT model and new targeted approach based model and its calibration and validation, (3) comparison of the model outputs between the conventional and new targeting approach, and (4) application of the new targeting approach to simulate second-generation biofuel crops, namely Alamo switchgrass (hereafter referred to as "switchgrass") and giant miscanthus (hereafter referred to as "miscanthus") on marginal lands in the LRW for analyzing their impacts on water quality.

\section{MATERiAls AND MethodS}

\subsection{STUDY AREA}

The LRW is located in the Mississippi Delta ecoregion of east central Arkansas and designated by the hydrological unit code (HUC) 08020205 (Seaber, 1994) (Fig. 2). The total drainage area for this watershed is 2,474 square kilometers that covers a portion of Craighead, Cross, Lee, Poinsett, St. Francis, and Woodruff counties. Various land uses and land covers in the LRW watershed are soybean [Glycine max (L.) Merr.] (43.6\%), forest (18.9\%), rice (Oriza sativa) (14.9\%), cotton (Gossypium hirsutum) (6.9\%), pasture (5.1\%), corn (Zea mays L.) (4.5\%), urban (3.5\%), water (1.4\%), and generic agriculture (mixed land uses that are not statistically significant: tomatoes, watermelon, etc.) (1.2\%) (CAST, 2007). The Arkansas Department of Environmental Quality (ADEQ) has included the L'Anguille River in the list of impaired water bodies for dissolved oxygen, chlorides, total dissolved solids, and sulfates (ADEQ, 2012). Moreover, the Arkansas Natural Resources Commission (ANRC) has designated the LRW as a priority watershed for the 2011-2016 NPS Pollution Management Plan for nutrients (ANRC, 2012). 


\section{Mississippi Delta ecoregion of north-eastern Arkansas}

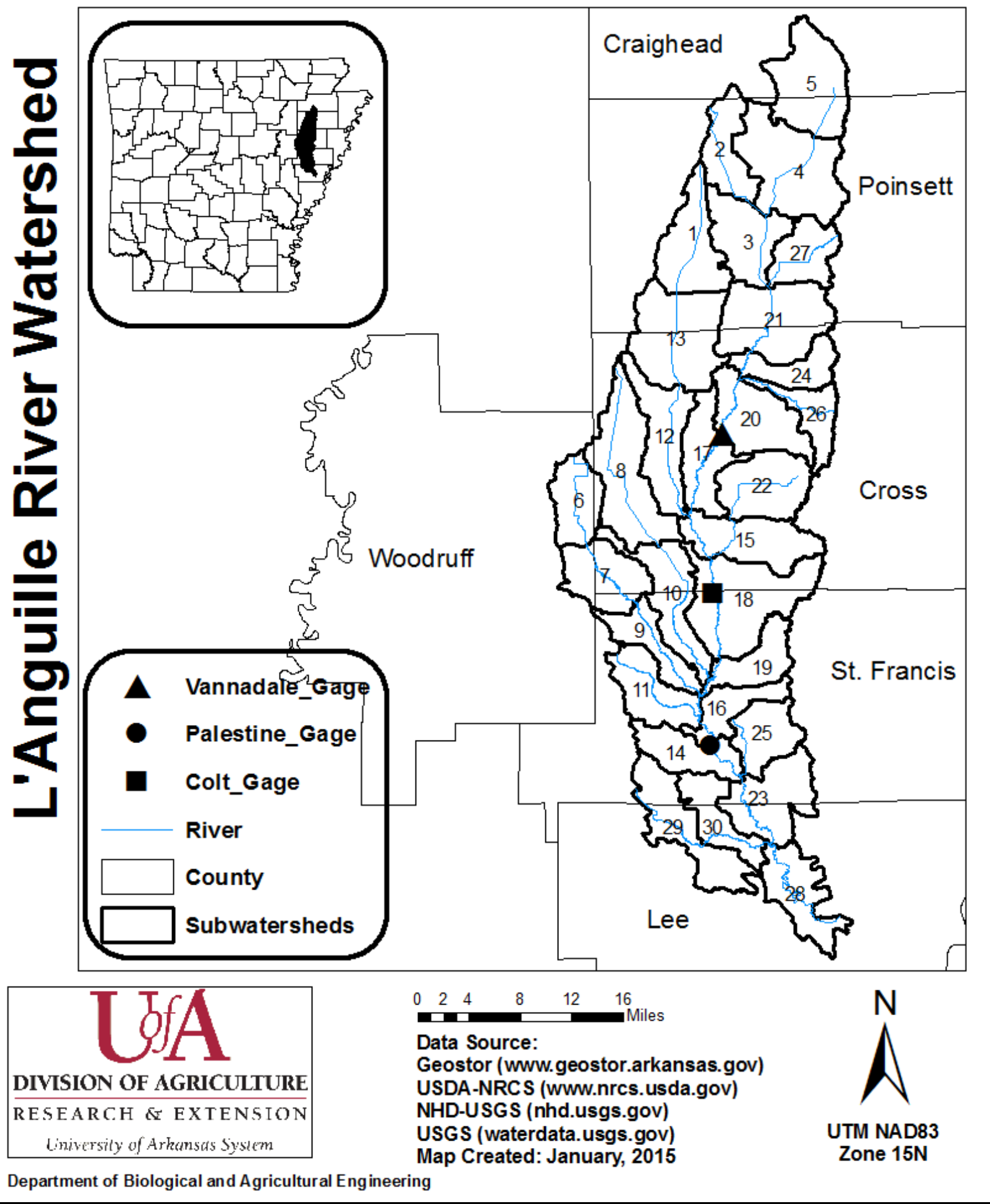

Fig. 2. Location of the L'Anguille River Watershed and subwatershed boundaries. 


\subsection{DEVELOPMENT OF A NEW TARgETING APPROACH}

A subset of Land Capability Class (LCC) classification, which is part of Soil Survey Geographic (SSURGO) data, was used for identifying marginal land in this study. The SSURGO LCC ranges from I to VIII according to soils capacity for supporting crop production. LCC I to IV could be used for agricultural purposes while classes V to VIII are meant for recreational activities, urban areas, etc. (NRCS, 2012). As LCC I and II are considered most favorable for food crop production; LCC III and IV were selected to represent marginal lands for the simulation of switchgrass and miscanthus. Based on the SSURGO LCC III and IV, a marginal land layer for the LRW was created in ArcMap/ArcGIS (version 9.3.1). This marginal land layer depicts the spatial distribution of marginal land in the LRW covering $52 \%$ of its area and was processed with the original LULC layer to generate a modified LULC layer. It should be noted that we selected one of the many ways in which marginal lands can be delineated but the GISbased approach explained in this paper could also be used to find marginal lands using other approaches discussed in the literature.

Development of a new targeting approach is needed for locating HRUs only on specific land use types thereby, overcoming the limitation of spatial discontinuity among HRUs. The targeting approach evaluated in this research used a modified LULC data layer that was developed as per the procedure described later. Typically, a conventional SWAT model setup generates HRU by processing soils, slope, and original land use and land cover (LULC) data. In this study, the model setup used a modified LULC layer along with soils and slope data to separately identify marginal and non-marginal HRUs in the model (Fig. 3). This modified LULC layer was prepared by processing the original LULC layer with the marginal land, thereby splitting the actual land uses into marginal and non-marginal components. 
The land uses that overlapped marginal land were labeled as a new category in the modified LULC layer. SWAT's procedure for identifying land uses using four letter codes was followed while developing new categories. Therefore, if some portion of a land use (say soybean) overlapped marginal land, that portion of soybean (SOYB) was reclassified as a new land use category and named SOYM instead of SOYB. This resulted in two sub-categories for soybean: one on marginal land (SOYM) and the other on non-marginal land (SOYB). All new land use categories (e.g. SOYM) were incorporated in the "look up table" that linked the numerical values of land uses in the attribute table of the modified LULC layer with their respective land uses names. The look up table includes all reclassified marginal and non-marginal land use categories.

SWAT has a default land cover/plant growth database (crop.dat) including land cover/plant growth parameters for common land uses designated with four letter codes (e.g. SOYB). The new land use categories (e.g. SOYM) were also defined in SWAT's land cover/plant growth database with the same parameter values as that of original land use (e.g. SOYB). The crop management practices for SOYB and SOYM were kept the same as both differ only on the basis of marginal land criteria. Therefore, nine land uses (in the original LULC layer) were reclassified into 18 land use categories (in the modified LULC layer).

\subsection{SWAT MODEL INPUTS}

The SWAT model (SWAT2009, rev. 488) is a watershed scale model used for predicting the impacts of land use and management on hydrology, sediment, and agricultural chemical yields on a daily basis (Arnold et al., 2012). To prepare input files, SWAT uses ArcSWAT, which is an extension of ArcMap/ArcGIS (ESRI, 2012). Major SWAT 
components include weather, hydrology, soil temperature and properties, plant growth, nutrients, pesticides, bacteria and pathogens, and land management practices (Arnold et al., 2012). In this study, SWAT was used to simulate switchgrass and miscanthus on marginal lands in the LRW. SWAT inputs for the LRW were obtained from several state and national agencies (Table 1). All data layers were downloaded in the North American Datum 1983 (NAD83) Universal Transverse Mercator Zone 15N (UTM-Zone 15N) projection system. Apart from the new modified LULC layer, all inputs were the same for both the conventional and new approach. The modified LULC layer with 18 reclassified land uses were input into the SWAT model as part of the new approach. 
Table 1. Model inputs for the L'Anguille River watershed.

\begin{tabular}{|c|c|c|c|}
\hline Data Type & Scale/Stations & Source & Description \\
\hline Topography & $5 \mathrm{~m}$ & $\begin{array}{l}\text { Geostor Arkansas } \\
\text { (http://www.geostor.arkansas.gov) }\end{array}$ & Digital Elevation Model \\
\hline $\begin{array}{l}\text { Land Use/Land } \\
\text { Cover (LULC) }\end{array}$ & $30 \mathrm{~m}$ & $\begin{array}{l}\text { Center for Advanced Spatial } \\
\text { Technologies (CAST) } \\
\text { (http://www.cast.uark.edu) } \\
\text { National Land Cover Dataset } \\
\text { (NLCD) } \\
\text { (http://www.mrlc.gov) }\end{array}$ & 1992, 2001 LULC \\
\hline Soil types & $150 \mathrm{~m}$ & $\begin{array}{l}\text { United States Department of } \\
\text { Agriculture-Natural Resources } \\
\text { Conservation Service (USDA- } \\
\text { NRCS) } \\
\text { (http://www.nrcs.usda.gov) }\end{array}$ & $\begin{array}{l}\text { Soil Survey Geographic (SSURGO) } \\
\text { database }\end{array}$ \\
\hline $\begin{array}{l}\text { Watershed } \\
\text { boundary }\end{array}$ & $1: 24000$ & $\begin{array}{l}\text { United States Department of } \\
\text { Agriculture-Natural Resources } \\
\text { Conservation Service (USDA- } \\
\text { NRCS) } \\
\text { (http://www.nrcs.usda.gov) }\end{array}$ & 12 digit watershed boundary dataset \\
\hline Stream network & $1: 24000$ & $\begin{array}{l}\text { National Hydrographic Dataset- } \\
\text { USGS (NHD-USGS) } \\
\text { (http://nhd.usgs.gov/) }\end{array}$ & $\begin{array}{l}\text { High resolution stream reaches } \\
\text { (February, 2008) }\end{array}$ \\
\hline Weather & $\begin{array}{l}4 \text { Stations } \\
\text { NEXRAD }\end{array}$ & $\begin{array}{l}\text { National Oceanographic and } \\
\text { Atmospheric Administration } \\
\text { (NOAA) } \\
\text { (http://www.noaa.gov/) } \\
\text { Lower Mississippi River } \\
\text { Forecasting Center (LMRFC) } \\
\text { (http://www.srh.noaa.gov/lmrfc/) }\end{array}$ & $\begin{array}{l}29 \text { years (1980 to } 2008 \text { ) of daily } \\
\text { temperature and precipitation } \\
\text { NEXRAD dataset from } 1996 \text { to } \\
2003\end{array}$ \\
\hline $\begin{array}{l}\text { Point source } \\
\text { pollution }\end{array}$ & 18 stations & $\begin{array}{l}\text { Arkansas Department of } \\
\text { Environmental Quality (ADEQ) } \\
\text { (http://www.adeq.state.ar.us/) }\end{array}$ & $\begin{array}{l}\text { Monthly flow, sediment and } \\
\text { nutrients (1990-2008) }\end{array}$ \\
\hline $\begin{array}{l}\text { Crop } \\
\text { management } \\
\text { information }\end{array}$ & County level & $\begin{array}{l}\text { University of Arkansas } \\
\text { Cooperative Extensive Service } \\
\text { (UACES) }\end{array}$ & $\begin{array}{l}\text { Fertilizer, pesticide and irrigation } \\
\text { application rates and timings; } \\
\text { tillage, planting and harvesting } \\
\text { information }\end{array}$ \\
\hline
\end{tabular}

\subsection{SWAT MODEL SETUP}

HRUs are generally created using thresholds for land use, soil and slope due to the presence of numerous HRUs in the watershed (can exceed 1000). These thresholds are often set to save processing time. A threshold of 0-10-0 for land use, soil, and slope, respectively was used for both the conventional and new approach as a compromise between spatial resolution and computational time. Both models were run from 1986 to 2008 with 1986 to 1989 as warm-up period. The warm-up period was used as it helps in stabilizing several model parameters (Bekiaris et al., 

as for the calibration and validation of the model to determine sediment, TP, and total nitrogen (TN) losses.

\subsection{Sensitivity Analysis, Calibration and Validation of the SWAT MOdel and Model Performance} EVALUATION

Sensitivity analysis is the procedure to identify parameters that have relatively greater influence on output variables (White and Chaubey, 2005). Latin Hypercube sampling — One factor At a Time (LH-OAT) method incorporated in the ArcSWAT interface (version 2009.93.7b) — was used in this study to conduct sensitivity analysis at the Colt station. As Colt and Palestine are hydrologically connected, the sensitive parameters for flow at Colt was assumed the same for flow at Palestine. Sensitivity analysis for water quality variables at Palestine was not conducted, as there was insufficient water quality data available than what was required for calibration purposes in this study. LH method divided the range of parameters into 10 parts, while OAT method selected each parameter randomly one at a time. Sensitivity analysis was carried out for 26 flow and six sediment related parameters resulting in 270 and 70 simulations, respectively. For TP and nitrate-nitrogen $\left(\mathrm{NO}_{3}-\mathrm{N}\right)$, sensitivity analysis was carried out for nine parameters resulting in 100 simulations.

Calibration represents the procedure of adjusting model parameters within reasonable ranges to simulate the observed dataset as closely as possible. The adjusted parameters are often the sensitive parameters that are ranked highest (Migliaccio and Chaubey, 2007). Validation represents the procedure to compare an independent dataset with model outputs without any adjustment of model parameters. Mostly modeling studies calibrate and validate at a single site (outlet) (Niraula et al., 2012). However, multi-site watershed calibration/validation is becoming an important approach for capturing spatial heterogeneity in watersheds (Ahmadi et al., 2014; Pai et al., 2011; White and Chaubey, 2005). In this study, we have also validated the model using short-term data available at another site, Vannadale, which was not used for calibration. Thus, the SWAT model was calibrated and validated at two sites, namely, Colt and Palestine, and separately validated at Vannadale site. At Colt and Palestine, daily flows were split into surface runoff and base flow using a digital filter developed by Arnold and Allen (1999). Time period for calibration and validation along with the variables selected for model performance assessment at the selected stations are presented in Table (2). Coefficient of determination $\left(\mathrm{R}^{2}\right)$, Nash-Sutcliffe efficiency (NSE), percent bias (PBIAS) and root mean square error-standard deviations ratio (RSR) were the four objective functions optimized on a monthly basis to simulate total flow, surface flow, base flow, sediment, $\mathrm{TP}$ and $\mathrm{NO}_{3}-\mathrm{N}$ (Moriasi et al., 2007) (Eq. [1-4]).

Table 2. Summary of measured data in the L'Anguille River watershed.

\begin{tabular}{|l|l|l|l|l|}
\hline $\begin{array}{l}\text { Monitoring } \\
\text { Station }\end{array}$ & $\begin{array}{l}\text { Drainage } \\
\text { Area (sq. } \\
\mathrm{km})\end{array}$ & Data Source & Time Period & $\begin{array}{l}\text { Calibrated/Validated Variables (SWAT } \\
\text { Outputs) }\end{array}$ \\
\hline Colt & 1302 & $\begin{array}{c}\text { USGS } \dagger \\
\text { (http://www.usg } \\
\text { s.gov/) }\end{array}$ & $\begin{array}{l}\text { Calibration }- \\
1990 \text { to } 2005 \\
\text { Validation }-\end{array}$ & $\begin{array}{l}\text { Total flow (FLOW_OUT cms) } \\
\text { Surface flow (((GW_Qmm + LAT_Qmm) / } \\
\text { WYLD mm) * FLOW_OUT cms) }\end{array}$ \\
\hline
\end{tabular}


$\dagger$ United States Geological Survey

†Ecological Conservation Organization

\section{High performance computing has increasingly been used for calibrating watershed models in the recent years} (Ercan et al., 2014; Rouholahnejad et al., 2012; Zhang et al., 2013). The current study also used Arkansas High Performance Computing Center supercomputers for compiling SWAT model. Studies have also reported the use of. autocalibration (Sloboda and Swayne, 2013; Wu and Liu, 2012) or manual calibration (Feyereisen et al., 2007) approaches for calibrating the SWAT models. However, manual calibration is preferred in cases where user's experience with the watershed helps in assigning a suitable parameter value as opposed to the automatic calibration. The automatic model calibrations may not provide acceptable parameter estimates for streamflow predictions (Boyle et al., 2000). It has also been reported that no automatic calibration procedure can take place for actual physical knowledge of the watershed (Arnold et al., 2012). The manual calibration technique was followed in this study to calibrate the model using data measured at Colt and Palestine. At Colt, the sequence followed for calibration was flow, sediment, TP, and $\mathrm{NO}_{3}-\mathrm{N}$ (Santhi et al., 2001; White and Chaubey, 2005). At Colt and Palestine, calibration was performed simultaneously. Moreover, the output statistics ( $\mathrm{R}^{2}$, NSE, PBIAS, and RSR) were optimized simultaneously as per the procedure reported by Migliaccio and Chaubey (2007). 


\subsection{Selection of Suitable Marginal Land, Land Cover/Plant Growth Parameters, and Crop Management Practices}

As mentioned earlier, the modified LULC layer resulted in 18 reclassified land uses. Out of these 18 reclassified land uses, nine overlapped marginal lands in the LRW. The overlapping land uses (soybean/SOYM, rice/RICM, corn/CORM, cotton/COTM, generic-agriculture/AGRM, forest/FRSM, pasture/PASM, urban/URBM, and water/WATM) constituted 52\% of the LRW area. However, based on the practicality of land use conversion, FRSM, PASM, URBM and WATM were discarded from the land use change analyses as switchgrass and miscanthus production on forest, pasture, urban land, and water is unlikely. Therefore, the available land uses for switchgrass and miscanthus simulation were soybean/SOYM, rice/RICM, corn/CORM, cotton/COTM, and genericagriculture/AGRM constituting about $39 \%$ of the watershed area. On an absolute area basis, marginal lands obtained with the conventional approach was found to be 209 square kilometers more than that obtained with the new approach (969 square kilometers). The obtained marginal lands in both the approaches were simulated with the switchgrass and miscanthus separately.

The land cover/plant growth parameters for switchgrass were already available in the SWAT land cover/plant growth database. However, two of its parameters were modified to simulate its growth characteristics in Arkansas (Chuck West, University of Arkansas, personal communication, 21 July 2011). Maximum potential leaf area index (BLAI), and maximum canopy height (CHTMX) were the modified parameters. BLAI was modified from 6 to 10 (dimensionless), and CHTMX was modified from 2.5 to $3 \mathrm{~m}$. As miscanthus is a relatively new biofuel crop, its land cover/plant growth parameters are not available in the SWAT land cover/plant growth database, and therefore had to be added into crop.dat file. Land cover/plant growth parameters for miscanthus as defined by $\mathrm{Ng}$ et al. (2010) were used in this study. All the land cover/plant growth parameters for switchgrass and miscanthus used in this study have been included in the supplementary data section (Table A1). For both switchgrass and miscanthus, same management practices were incorporated as per local recommendations (Dr. West, personal communication, 19 April 2012) (Table 3). Per Table (3), the management practices differ only for the first two years followed by no change from the third year forward. These management practices were converted into SWAT equivalent management operations. 
Table 3. Crop management practices for switchgrass and miscanthus.

\begin{tabular}{|c|c|c|c|c|}
\hline Date & Practice & Amount/acre & SWAT Practice & SWAT kg/ha \\
\hline \multicolumn{5}{|c|}{ First Year } \\
\hline Apr 20 & $\begin{array}{l}\text { Phosphorus, } \\
\text { Potassium } \\
\text { Application }\end{array}$ & $\begin{array}{l}36 \mathrm{lb} \text { phosphate } \\
\text { (P2O5), } 60 \mathrm{lb} \mathrm{K} 12\end{array}$ & $\begin{array}{l}\text { Fertilizer Application (00- } \\
40-60)\end{array}$ & $\begin{array}{l}112 \text { (19.5 Elemental P, } \\
55.7 \text { Elemental K) }\end{array}$ \\
\hline Apr 20 & Disking & & $\begin{array}{l}\text { Tillage (Disk Plow } \\
\text { Ge23ft) }\end{array}$ & \\
\hline Apr 21 & Roller & & $\begin{array}{l}\text { Tillage (Roller Packer } \\
\text { Attachment) }\end{array}$ & \\
\hline May 20 & $\begin{array}{l}\text { Burn down with } \\
\text { glyphosate }\end{array}$ & $1 \mathrm{lb}$ a.i. & $\begin{array}{l}\text { Pesticide Application } \\
\text { (Glyphosate Amine) }\end{array}$ & 1.12 \\
\hline May 21 & Planting & & $\begin{array}{l}\text { Plant/Begin Growing } \\
\text { Season }\end{array}$ & \\
\hline Jun 20 & Weed control & 0.25 a.i. & $\begin{array}{l}\text { Pesticide Application (2,4- } \\
\text { D Amine) }\end{array}$ & 0.28 \\
\hline \multicolumn{5}{|c|}{ Second Year } \\
\hline Apr 1 & $\begin{array}{l}\text { Nitrogen } \\
\text { Application }\end{array}$ & 70 lb Urea & $\begin{array}{l}\text { Fertilizer Application } \\
\text { (Urea) }\end{array}$ & 78.46 \\
\hline Jun 20 & Weed control & $0.25 \mathrm{lb}$ a.i. & $\begin{array}{l}\text { Pesticide Application (2,4- } \\
\text { D Amine) }\end{array}$ & 0.28 \\
\hline Nov 1 & Harvest & & $\begin{array}{l}\text { Harvest Only (100\% } \\
\text { Harvesting Efficiency) }\end{array}$ & \\
\hline \multicolumn{5}{|c|}{ From Third Year Onwards } \\
\hline Apr 1 & $\begin{array}{l}\text { Nitrogen } \\
\text { Application }\end{array}$ & 70 lb Urea & $\begin{array}{l}\text { Fertilizer Application } \\
\text { (Urea) }\end{array}$ & 78.46 \\
\hline Nov 1 & Harvest & & $\begin{array}{l}\text { Harvest Only (100\% } \\
\text { Harvesting Efficiency) }\end{array}$ & \\
\hline
\end{tabular}

\subsection{YIELD ANALYSIS}

A further analysis to evaluate the level of confidence in model simulations was also performed in addition to calibration and validation. This analysis involved comparing the simulated yields for switchgrass and miscanthus with field values reported in literatures. In general, crop yield accounts for evapotranspiration and soil moisture required for vegetative growth. As a result, crop yield can serve as an alternative for evaluating the evapotranspiration and soil moisture within the hydrological budget (Srinivasan et al., 2010). Area-weighted annual simulated yields were obtained for switchgrass and miscanthus. The annual yields were then averaged over the 19year study period (1990 to 2008) to obtain the area-weighted average annual yield for switchgrass and miscanthus. The obtained long-term area-weighted average annual yields were compared with the literature values.

\subsection{COMPARISON BETWEEN CONVENTIONAL AND NEW APPROACH}

Conventional approach represents typical SWAT modeling approach in which switchgrass/ miscanthus was simulated on marginal HRUs. However, the fact that switchgrass/ miscanthus could also be simulated on other HRUs within subwatersheds because of the spatial discontinuity among same HRUs was not acknowledged. The 
new approach represents a way by which switchgrass/miscanthus was simulated only on targeted marginal HRUs. Area-weighted annual pollutant losses (sediment, TP, and TN) exiting the marginal HRUs to their respective subwatershed's reach were obtained for both the conventional and new approaches. Area-weighted annual pollutant losses were averaged over the 19-year study period (1990 to 2008) and compared for the conventional and new approach. In this study, TP loss represents the sum of organic, sediment, and soluble phosphorus exiting the marginal HRUs while TN loss represents the sum of $\mathrm{NO}_{3}-\mathrm{N}$ and organic nitrogen loss in surface runoff, as well as $\mathrm{NO}_{3}-\mathrm{N}$ loss in lateral and groundwater flows exiting the marginal HRUs. TN instead of $\mathrm{NO}_{3}-\mathrm{N}$ was selected for analyzing the nitrogen losses as it includes surface, lateral and groundwater nitrogen losses. Equations [5] and [6] for pollutant losses resulting from the conventional and new approach are as follows:

Conventional Approach:

$$
\text { X_trad = X_marginal }+X \_n o n \_m a r g \text { inal }
$$

Where X_trad is the conventional pollutant loss from all the marginal and non-marginal HRUs, X_marginal is the pollutant loss from the switchgrass/ miscanthus simulated marginal HRUs, and X_non_marginal is the pollutant loss from the non-marginal HRUs.

New Approach:

$$
\text { X_new }=\text { X_marginal _targeted }+ \text { X_marginal _nontarget ed }+ \text { X_non_marg inal }
$$

Where X_new is the new pollutant loss from the targeted and nontargeted marginal HRUs as well as nonmarginal HRUs, X_marginal_targeted is the pollutant loss from the switchgrass/ miscanthus simulated targeted marginal HRUs, X_marginal_nontargeted is the pollutant loss from the non-targeted marginal HRUs, and X_non_marginal is the pollutant loss from the non-marginal HRUs.

X_non_marginal was common in both the conventional and new approach. Only the X_marginal in the new approach has been splitted into X_marginal_targeted and X_marginal_nontargeted. The X_marginal for the conventional approach was compared with the $\mathrm{X} \_$marginal_targeted for the new approach.

\subsection{WATER QUALITY IMPACTS}

Area-weighted annual sediment, TP, and TN losses were obtained for the current row crops on marginal HRUs. These annual sediment, TP, and TN losses exiting marginal HRUs to their respective subwatershed's reach were termed as baseline losses. Annual baseline losses were averaged over the 19-year study period and were compared with the area-weighted average annual losses resulting from the marginal HRUs simulated with switchgrass and miscanthus, respectively. Switchgrass and miscanthus were simulated separately. In other words, switchgrass was simulated first on all the marginal land followed by the simulation of miscanthus. As switchgrass and miscanthus were simulated separately, the probable causes for the differences between the reductions obtained by simulating switchgrass on marginal land compared to simulating miscanthus on marginal land were also analyzed. 


\section{RESULTS AND DISCUSSION}

\subsection{SENSITIVITY ANALYSIS}

Colt

Hydrology: The identified sensitive parameters for hydrology are shown in Table (4). CN2 was ranked as the most sensitive parameter for flow that mainly affects the overland flow process. Saraswat et al. (2008) identified two dominant hydrological soil groups in the LRW: soil group C and D. These dominant soil groups have been reported to have high runoff potentials (USDA-NRCS, 2009). As a result, it was no surprise that the overland hydrologic process mainly affected the flow in the LRW. Flow and CN2 was related with the modified soil conservation service (SCS) curve number equation. A higher sensitivity for the ESCO was because of the fact that LRW, located in the southern United States, receives higher solar radiation. Parameters CN2 and ESCO were also identified as sensitive for the LRW by Maringanti (2008).

Table 4: Sensitive parameters ranking from high to low for hydrology, sediment, total phosphorus, and nitrate nitrogen at the Colt station.

\begin{tabular}{|c|c|}
\hline Variable & Description \\
\hline \multicolumn{2}{|l|}{ Hydrology } \\
\hline $\mathrm{CN} 2$ & Curve number for the moisture condition II \\
\hline ESCO & Soil evaporation compensation factor \\
\hline SOL_AWC & Available water capacity in the soil \\
\hline GWQMN & Depth of water which is necessary for the occurrence of the groundwater flow \\
\hline BLAI & Maximum potential leaf area index \\
\hline \multicolumn{2}{|l|}{ Sediment } \\
\hline USLE_P & Support practice factor of the Universal Soil Loss Equation equation \\
\hline SPCON & $\begin{array}{l}\text { Cofficient provided by the user in simulating the maximum amount of sediment that is } \\
\text { allowed to transport from a reach segment }\end{array}$ \\
\hline USLE_C & Minimum value of USLE C factor for water erosion applicable to the land cover/plant \\
\hline SPEXP & $\begin{array}{l}\text { Exponent cofficient required to be provided by the user in simulating the maximum } \\
\text { amount of sediment that is allowed to transport from a reach segment }\end{array}$ \\
\hline CH_COV2 & channel cover factor \\
\hline \multicolumn{2}{|l|}{ Total Phosphorus } \\
\hline PHOSKD & Phosphorous soil partitioning cofficient \\
\hline PPERCO & Phosphorous percolation cofficient \\
\hline NPERCO & Nitrate percolation coefficient \\
\hline RCHRG_DP & Deep aquifer percolation fraction \\
\hline SHALLST_N & Initial concentration of nitrate in the shallow aquifer \\
\hline Nitrate Nitrogen & \\
\hline
\end{tabular}




\begin{tabular}{|c|c|}
\hline RCHRG_DP & Deep aquifer percolation fraction \\
\hline NPERCO & Nitrate percolation coefficient \\
\hline PHOSKD & Phosphorous soil partitioning cofficient \\
\hline PPERCO & Phosphorous percolation cofficient \\
\hline SHALLST_N & Initial concentration of nitrate in the shallow aquifer \\
\hline
\end{tabular}

Sediment: The identified sensitive parameters for sediment are shown in Table (4). By definition, USLE_P represents the ratio of soil loss from a specific support practice (contour tillage, strip cropping, etc.) to the loss from an up and down slope culture (Arnold et al., 2011). USLE_P, being the most sensitive parameter for the sediment yield, indicated that a change in the land use practice factor would affect the sediment loadings. Sediment yield and USLE_P was related by the modified universal soil loss equation (MUSLE). USLE_C can affect the sediment loadings due to the change in crop and management factors indicating that a change in the LULC in LRW would affect the sediment loadings. Channel processes also played a role in affecting sediment loadings as depicted by SPCON, SPEXP, and CH_COV2. As the LRW is a sediment impacted watershed and identification of sedimentation sources from L'Anguille River banks was recommended by the Nine-Element Watershed Restoration Plan (Audubon, 2005), it was expected that the sediment losses would be influenced by both overland and channel processes.

TP: The identified sensitive parameters for TP are shown in Table (4). PHOSKD representing the soluble phosphorus concentration in the surface $10 \mathrm{~mm}$ of soil divided by the soluble phosphorus concentration in surface runoff (Arnold et al., 2011) was identified as the most sensitive parameter for the TP. PHOSKD was also related to the overland process similar to CN2 and USLE_P. As a result, it was observed that the overland process affects most of the flow, sediment, and TP. Moreover, there was a predictable correlation between sediment and TP because of the ability of phosphorus to bind over and transport with sediments. In general, PHOSKD value mainly changes with the diffusion process (i.e. migration of ions in the soil solution as a response to the concentration gradient) (Arnold et al., 2011).

$\mathrm{NO}_{3}-\mathrm{N}$ : The identified sensitive parameters for $\mathrm{NO}_{3}-\mathrm{N}$ are shown in Table (4). RCHRG_DP representing the fraction of percolation from the root zone that recharges the deep aquifer (Arnold et al., 2011) was ranked as the most sensitive parameter for $\mathrm{NO}_{3}-\mathrm{N}$. Because the movement of $\mathrm{NO}_{3}-\mathrm{N}$ is mainly an underground process, it was no surprise that RCHRG_DP was ranked as the most sensitive parameter.

\subsection{CAlibration AND Validation}

Parameters were adjusted during the multi-site (Colt and Palestine), multi-variable (total flow, surface flow, base flow, sediment, TP, and $\mathrm{NO}_{3}-\mathrm{N}$ ), and multi-objective ( $\mathrm{R}^{2}, \mathrm{NSE}, \mathrm{PBIAS}$, and RSR) calibration. These adjustments were made within the ranges recommended by the SWAT manual. As sensitivity analysis assumes linearity and does not consider correlations between parameters (White and Chaubey, 2005), adjusted parameters were not all the same as sensitive parameters. In other words, some parameters (not mentioned above) were selected to make a better fit 
for the measured and simulated data (Santhi et al., 2001). All the parameters adjusted during the calibration of the model have been shown in Table (5).

Table 5: Parameters adjusted during model calibration, their ranges, and final used values.

\begin{tabular}{|c|c|c|c|c|}
\hline Variable & Unit & Input file & $\begin{array}{l}\text { Recommended Range } \\
\text { in SWAT }\end{array}$ & Actual Value Used \\
\hline $\mathrm{CN} 2$ & None & $\mathrm{mgt}$ & $35-98$ & $\pm 10 \%$ \\
\hline ESCO & None & bsn & $0-1$ & 0.7 \\
\hline SOL_AWC & $\mathrm{mm} / \mathrm{mm}$ & sol & $0-1$ & $\begin{array}{l}\text { Varies per the soil } \\
\text { type and layers }\end{array}$ \\
\hline GWQMN & $\mathrm{mm}$ & gw & $0.0-5000$ & 600 \\
\hline BLAI & $\mathrm{m} 2 / \mathrm{m} 2$ & crop & $0.5-10$ & No Change \\
\hline USLE_P & None & $\mathrm{mgt}$ & $0-1$ & 0.2 \\
\hline SPCON & None & bsn & $0.0001-0.01$ & 0.001 \\
\hline USLE_C & None & Crop & $0.001-0.5$ & No Change \\
\hline SPEXP & None & bsn & $1-2$ & 1.4 \\
\hline CH_COV2 & None & rte & $0.001-1$ & 0.5 \\
\hline PHOSKD & $\mathrm{m}^{3} / \mathrm{Mg}$ & bsn & $100-200$ & 200 \\
\hline PPERCO & $\mathrm{m}^{3} / \mathrm{Mg}$ & bsn & $10-17.5$ & 10 \\
\hline NPERCO & None & bsn & $0-1$ & 0.05 \\
\hline RCHRG_DP & None & gw & $0-1$ & 0.004 \\
\hline SHALLST_N & $\mathrm{Mg} \mathrm{N} / \mathrm{l}$ & gw & $0-1000$ & 10 \\
\hline ALPHA_BF & days & gw & $0-1$ & 0.17 \\
\hline GW_REVAP & None & gw & $0.02-0.20$ & 0.02 \\
\hline CH_N2 & None & rte & $0-0$ & 0.014 \\
\hline PRF & None & bsn & $0-2$ & 0.125 \\
\hline SURLAG & None & bsn & $1-24$ & 12 \\
\hline$\overline{\text { SOL_Z }}$ & $\mathrm{mm}$ & sol & $0-3500$ & $\begin{array}{l}\text { Varies per the soil } \\
\text { type and layers }\end{array}$ \\
\hline CH_K2 & $\mathrm{mm} / \mathrm{hr}$ & rte & $0-500$ & 65 \\
\hline SDNCO & None & bsn & $0-1$ & 0.1 \\
\hline $\mathrm{CDN}$ & None & bsn & $0-3$ & 3 \\
\hline
\end{tabular}

\subsubsection{Colt}

Statistical and temporal results for the calibration and validation at Colt are shown in Fig. (4) and Fig. (5). $R^{2}$ and NSE ranged from 0.4 to 0.9 and 0.5 to 0.9 , respectively. Therefore, most of the statistics for total flow, surface flow, base flow, sediment, TP and $\mathrm{NO}_{3}-\mathrm{N}$ were satisfactory at Colt and showed good correlation between measured and 
simulated values according to model evaluation guidelines provided by Moriasi et al. (2007). The percent bias (PBIAS) statistics indicated some under-prediction for total flow during the calibration period (positive biases) and over-prediction during the validation period (negative biases), which is also visible in Fig. (4). As per Fig. (4), there were high under-prediction for total flow during February 1998, 1999, and 2001, and January 2002, and high overprediction during March 2008. Studies have reported spatial variability as a major cause for the under and overprediction for flow (Santhi et al., 2001; Srinivasan et al., 1998). Against an average rainfall of $1152 \mathrm{~mm}$, rainfall in the LRW watershed varied between $1109 \mathrm{~mm}$ and $1271 \mathrm{~mm}$ during the period of under/over-prediction.

SWAT under-predicted sediments for the calibration period; however, validation results reflected that the model performance was very good. As sediment and flow were interrelated, errors in flow predictions were expected to propagate to sediments. Therefore, sediment under-prediction during February 1998 was likely to be propagated from flow under-prediction that is also visible in Fig. (5). TP statistics were good for the calibration and validation period, however SWAT under-predicted TP during calibration and over-predicted during validation. As most of the phosphorous transportation is through surface runoff (Haggard et al., 2003), the under and over-prediction of TP was related to flow. Calibration and validation for $\mathrm{NO}_{3}-\mathrm{N}$ had some over-predicted peaks while the remaining period was dominated by under-prediction. $\mathrm{R}^{2}$ for $\mathrm{NO}_{3}-\mathrm{N}(0.4)$ was little below the satisfactory level $(0.5)$ because in general $\mathrm{NO}_{3}-\mathrm{N}$ is difficult to calibrate, resulting in poor simulations (Chu et al., 2004). Overall, most of the statistics at Colt were satisfactory or better as per Moriasi et al., (2007). 


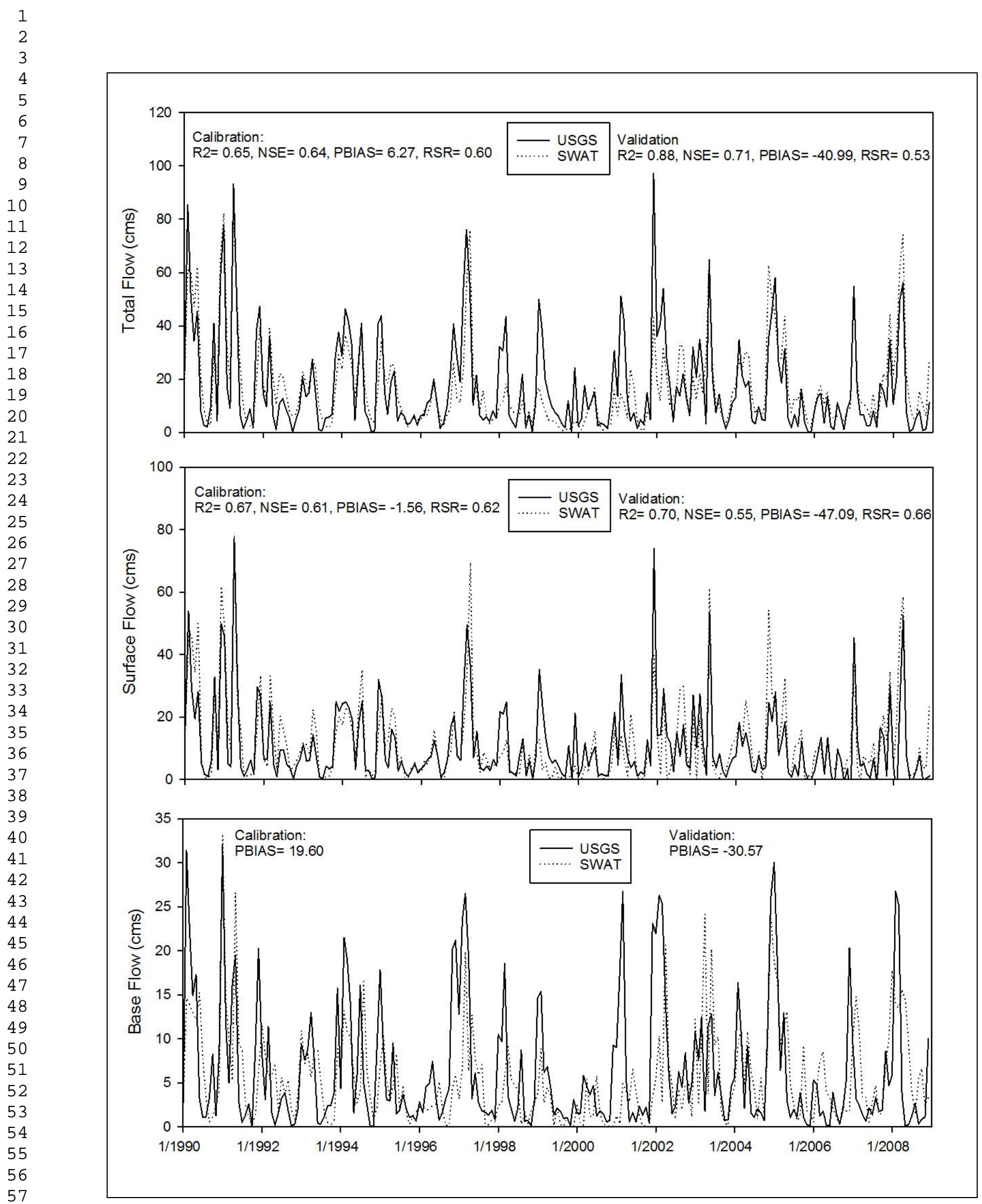

Fig. 4. Time series plots (monthly: 1990-2008) for total, surface, and base flow calibration and validation at Colt. 


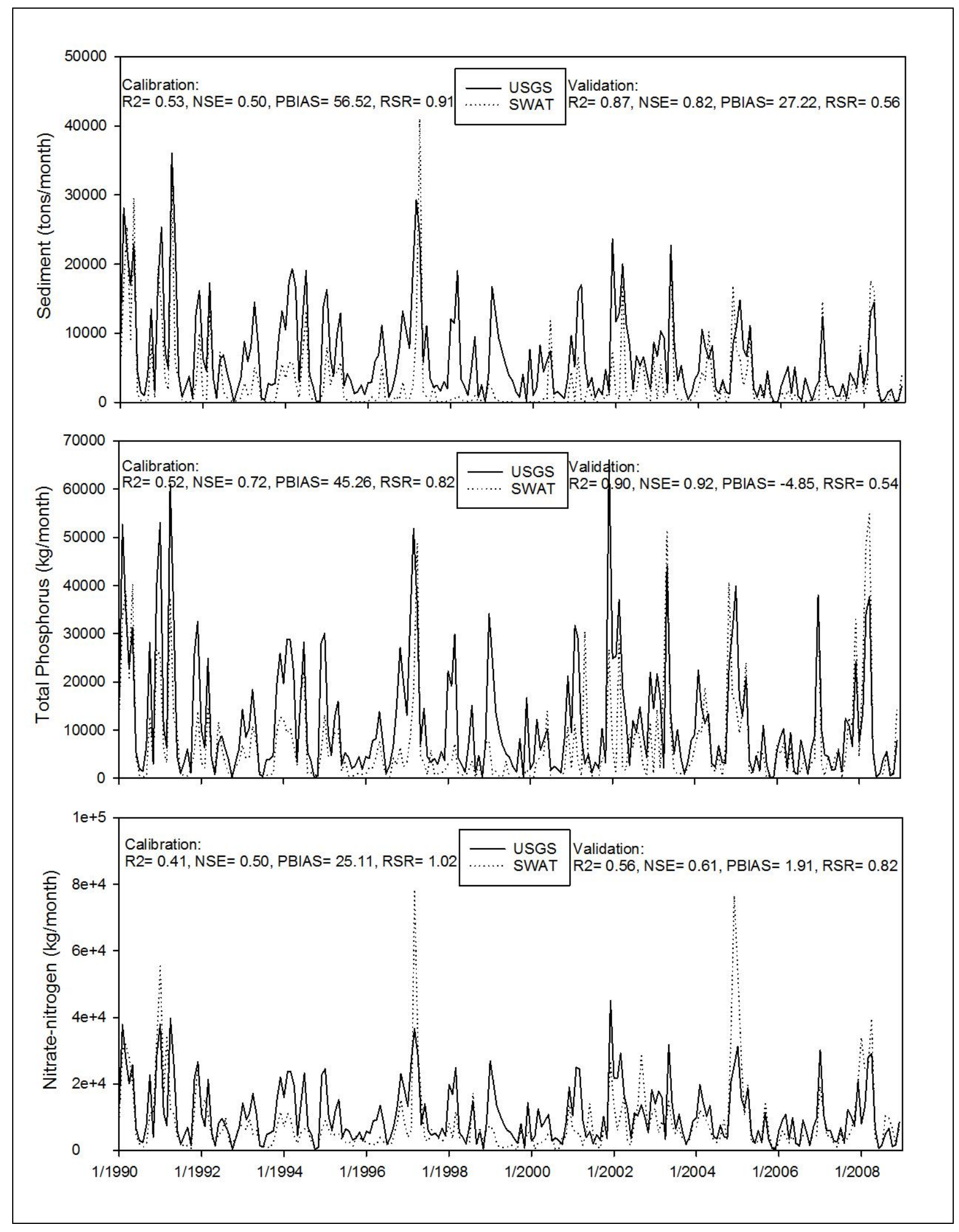

Fig. 5. Time series plots (monthly: 1990-2008) for sediment, total phosphorus, and nitrate-nitrogen calibration and validation at Colt. 


\subsubsection{Palestine}

Statistical and temporal results for the calibration and validation at Palestine are shown in Fig. (6). $\mathrm{R}^{2}$ and NSE ranged from 0.4 to 0.9 and 0.3 to 0.8 , respectively. Most of the statistics for total flow, surface flow, and base flow were satisfactory and showed good correlation between measured and simulated values as per the model evaluation guidelines provided by Moriasi et al. (2007). To some extent, total flow was under-predicted (positive biases) during calibration and over-predicted (negative biases) during validation. SWAT mainly under-predicted total flow in March 2001, January 2002 and May 2002, and over-predicted in January 2008 (Fig. 6). This under and overprediction is attributed to SWAT model's inability to simulate storm event as it is designated for long-term simulation. Surface flow was also somewhat under-predicted during the calibration and over-predicted during the validation period. Nonetheless, the model was considered satisfactory on a holistic basis due to the robustness of multi-site, multi-variable, and multi-objective calibration and validation. 

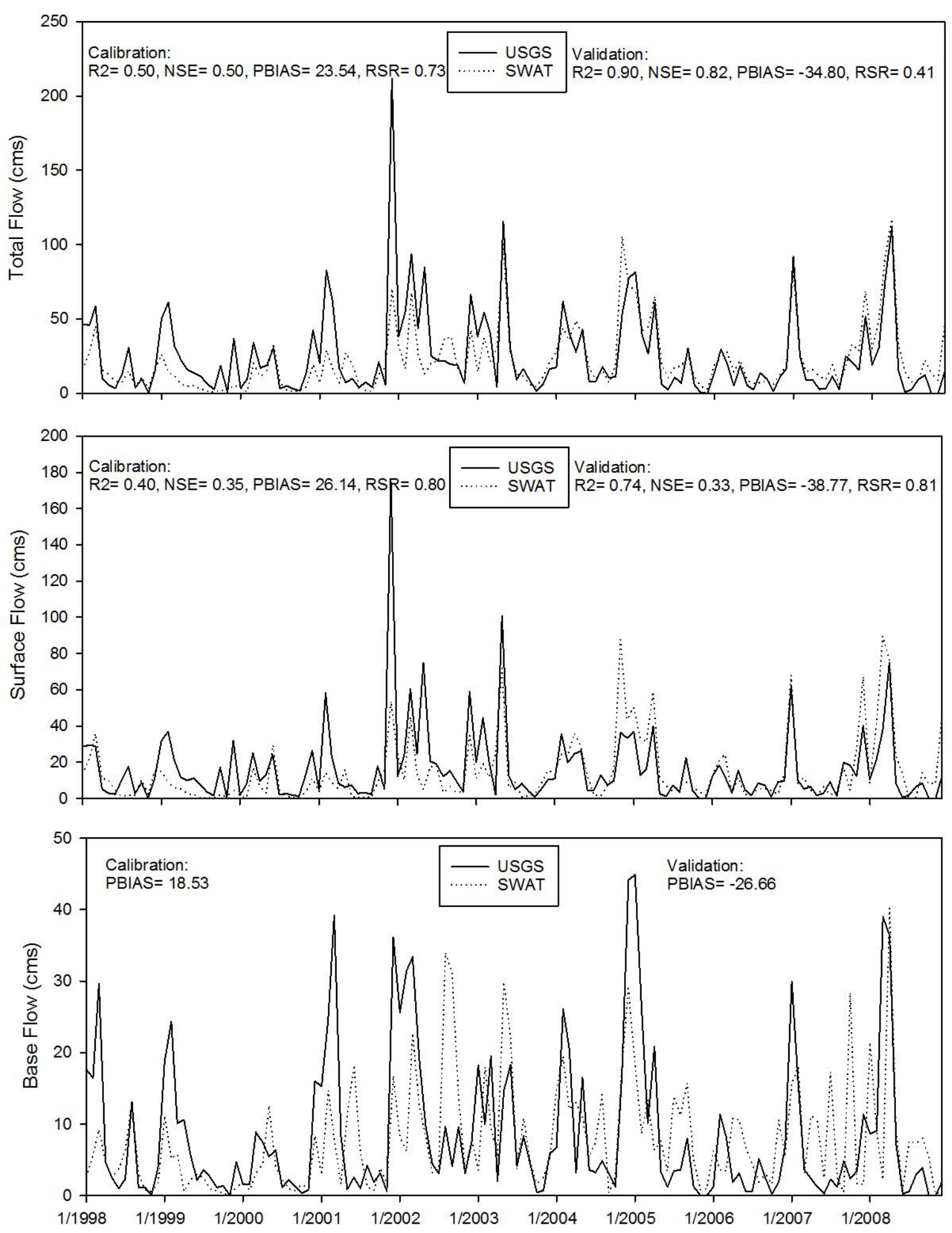

Fig. 6 Time series plots (monthly: 1990-2008) for total, surface, and base flow calibration and validation at Palestine. 


\subsubsection{Validation: Vannadale}

Most of the statistical results were satisfactory at Vannadale (Fig. A1 in the supplementary data section). Only $\mathrm{R}^{2}$ for $\mathrm{NO}_{3}-\mathrm{N}$ and NSE for total flow and sediment were below the satisfactory level as per the evaluation guidelines provided by Moriasi et al. (2007). However, these statistics were considered satisfactory based on the literature review (Cao et al., 2006; Onusluel and Rosbjerg, 2010; Qi and Grunwald, 2005; Santhi et al., 2001; Srinivasan et al., 1998; White and Chaubey, 2005).

\subsection{YIELD ANALYSIS}

The obtained area-weighted average annual (1990-2008) simulated yield for switchgrass and miscanthus was 7 and $9 \mathrm{Mg} / \mathrm{ha}$, respectively, and was compared with the yields expected for the Arkansas conditions. The expected yield for switchgrass in Arkansas can vary from 3-5 tons/ac (7-12 Mg/ha approx.) (Popp and Hogan, 2007). In Fayetteville, Arkansas, switchgrass yields ranged within 8-12 Mg/ha during field trials conducted by West et al. (2011). Although the SWAT-simulated yield for switchgrass in our study was slightly on the lower side of the expected yield for Arkansas conditions, the simulated yield was considered reasonable (Dr. West, personal communication, 26 June 2012). Reasonable value for switchgrass yield also indicates that the simulated evapotranspiration and moisture content values were better predicted (Srinivasan et al., 2010). As far as the lower yield is concerned, Baskaran et al. (2010) reported that the SWAT-predicted yields could be lower than the actual expected yields. It is understandable that as per some other studies, SWAT predicted yields were on the lower side of the expected yield for both switchgrass and miscanthus (Parish et al., 2012; Parajuli and Duffy, 2013). However, without site-specific data, the model cannot be improved further by modifying the crop growth parameters in the SWAT model. As a result, more site-specific data is needed in the future to improve the model performance.

\subsection{COMPARISON BETWEEN CONVENTIONAL AND NEW (TARGETED) APPROACH}

Average annual sediment, TP, and TN losses resulting from the simulated switchgrass and miscanthus were lesser for the new approach as compared to the conventional approach (Fig. 7). When compared to new approach, the conventional approach resulted in over-prediction of sediments by $20 \%$ and $61 \%$, TP by $17 \%$ and $53 \%$, and TN by $25 \%$ and $65 \%$ for the simulated switchgrass and miscanthus, respectively. This was expected because of the presence of fewer numbers of HRUs (only targeted marginal HRUs) under the new approach. For the current study, conventional approach resulted in simulating an additional area of 209 square $\mathrm{km}$ under switchgrass and miscanthus due to the model's limitation for excluding non-targeted HRUs. Other studies have also pointed out that targeting based approach is very much desired while using SWAT model (Busteed et al., 2009; Pai et al., 2011; White et al., 2009). Targeting land areas with due considerations to their spatial connectivity is advocated for presenting reliable results to watershed planners (Chaubey et al., 2005; Her et al., 2015).

A statistical analysis was performed to analyze if the mean loads resulting from the new simulation approach were statistically different from the loads resulting from the traditional approach. The t-test was performed to analyze the statistical significance levels. A p-value of 0.05 or less rejects the null hypothesis that the means loads are not significantly different from each other. As per the t-test results, the p-value came out to be less than 0.05 for 
sediment, TP, and TN. The results suggest that the mean loads resulting from the new and traditional simulation approach were statistically significant.
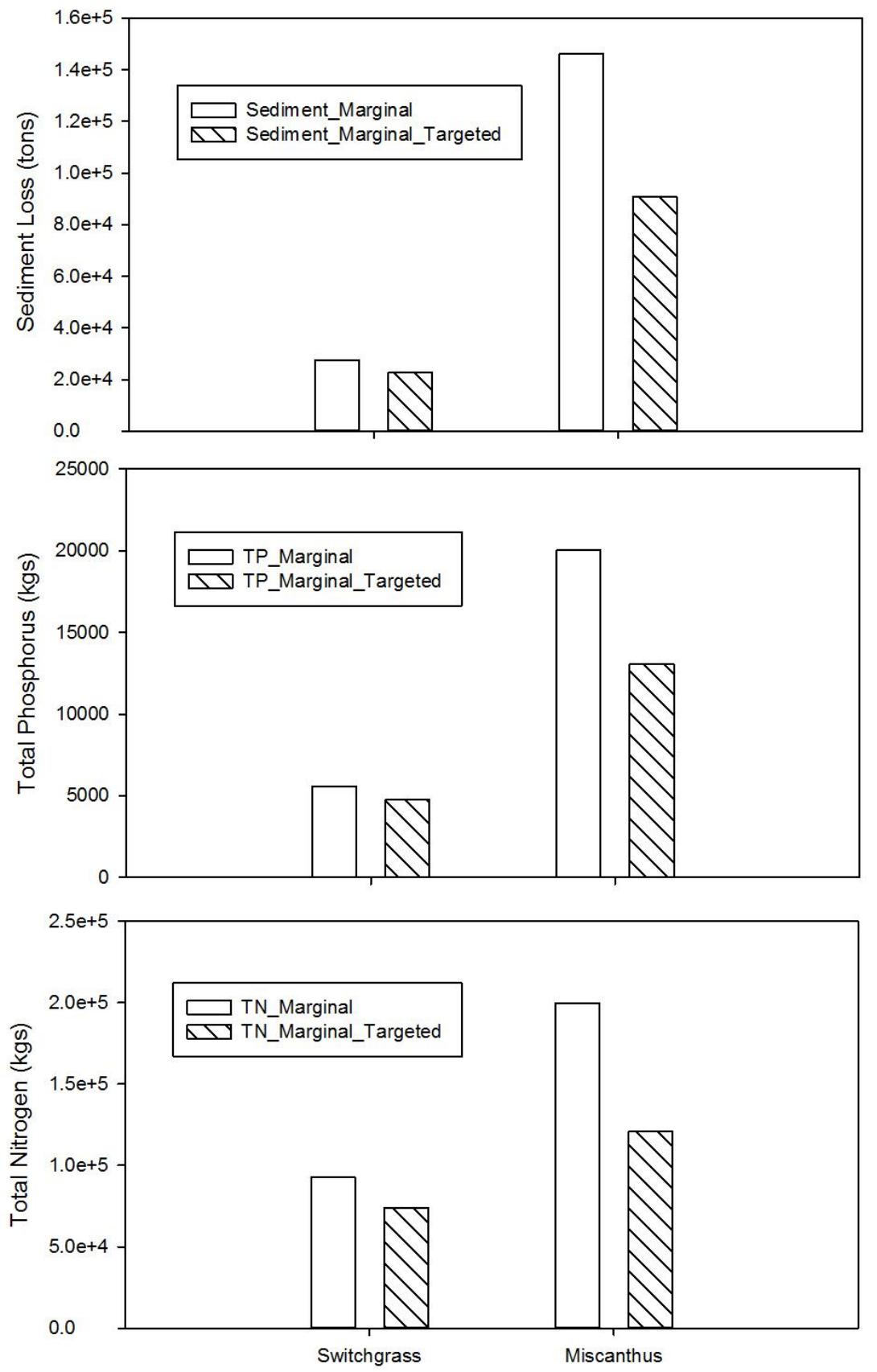

Fig. 7. Comparison between the conventional and new approach for the average annual sediment, total phosphorus, and total nitrogen losses resulting from the simulated switchgrass and miscanthus. 


\subsection{WATER QUALITY IMPACTS}

Compared to area-weighted average annual losses under baseline scenario (baseline represents the current cropping condition), simulation of switchgrass on marginal land resulted in 94\% decrease in sediment, $96 \%$ decrease in TP, and 80\% decrease in TN losses (Fig. 8). Similarly, simulation of miscanthus on marginal land resulted in $78 \%$ decrease in sediment, 90\% decrease in TP, and 67\% decrease in TN losses (Fig. $\underline{8}$ ). The decrease in sediment loss was due to the land cover/plant growth parameters and absence of tillage operations in switchgrass and miscanthus after their first year of establishment. Studies have reported decreased sediment losses in the absence of tillage practices (Giri et al., 2012; Yang et al., 2011). Additionally, switchgrass and miscanthus are closely grown, deeply rooted crops, thereby hindering the transport of sediments. The reductions in TP and TN losses compared to the baseline were because of the land cover/plant growth parameters and reduced fertilizer applications. Phosphate (36 pounds P2O5) was applied to switchgrass and miscanthus only in their first year of establishment. Additionally, the binding nature of phosphorus on the surface of sediments creates a predictable correlation between TP and sediments, thereby resulting in decreased TP due to the decrease in sediment losses. The $80 \%$ reduction in TN losses with the simulated switchgrass obtained in our study is similar to the $87 \%$ reduction for the one-cut mature switchgrass reported by Sarkar et al. (2011). In summary, simulation of switchgrass and miscanthus on marginal land reduced the sediment, TP, and TN losses exiting the marginal HRUs compared to the baseline losses.

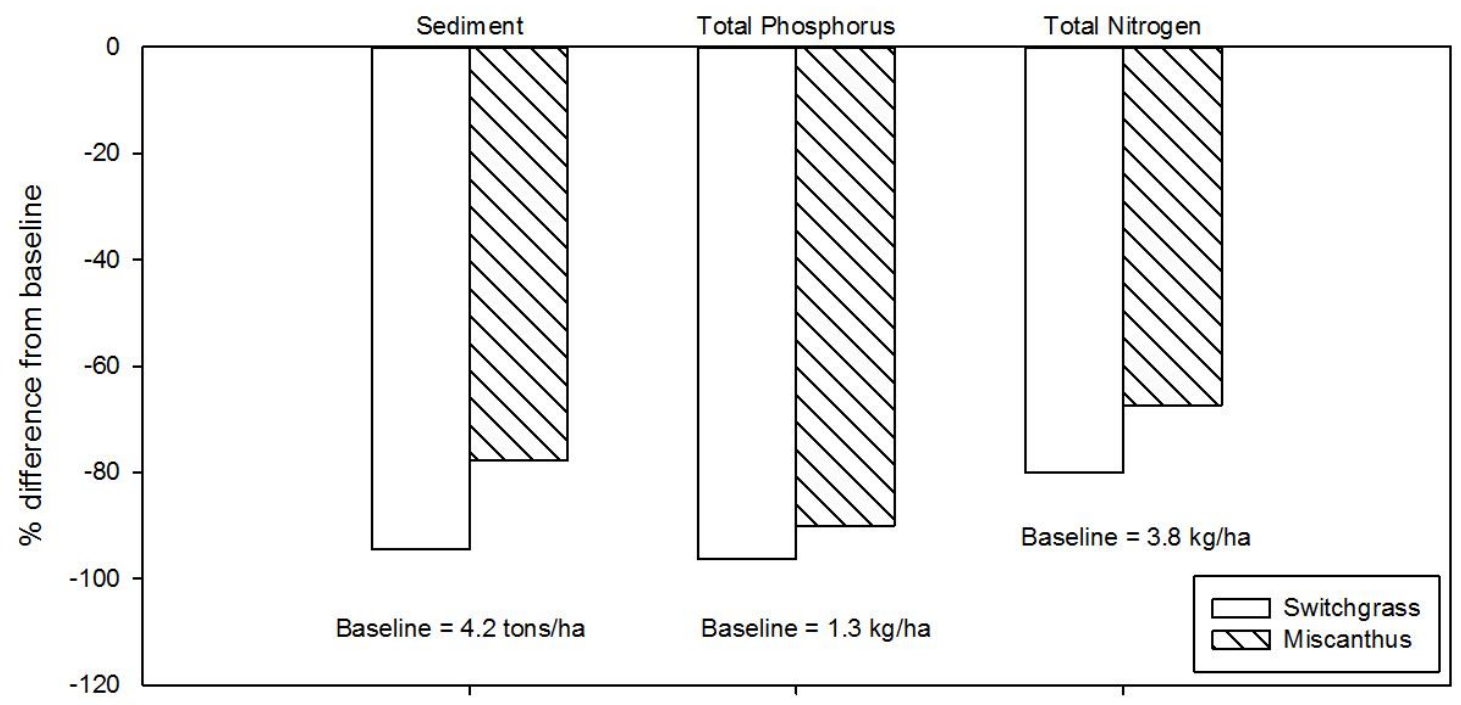

Fig. 8. Area-weighted average annual changes in sediment and nutrient losses resulting from the simulation of switchgrass and miscanthus on marginal land compared to the baseline scenario.

In general, management practices and land cover/plant growth parameters for crops are the two factors affecting the pollutant losses. In the present study, same management practices were defined for switchgrass and miscanthus (Dr. West, personal communication, 19 April 2012). As reductions in pollutant losses from the baseline with the simulated switchgrass were different than that obtained with the simulated miscanthus, it was hypothesized that these differences were because of the differences in land cover/plant growth parameters for switchgrass and 
miscanthus. This hypothesis has been verified by replacing all the land cover/plant growth parameters for switchgrass with the defined parameters for miscanthus. The model was run again and the obtained pollutant losses reductions observed with simulated switchgrass and miscanthus came out to be the same. Moreover, the impacts of individual land cover/plant growth parameters on the pollutant losses reductions were also explored. The land cover/plant growth parameters for switchgrass were replaced with the defined parameters for miscanthus one at a time, and the percentage reductions in sediment, TP, and TN were analyzed (Table A2 in the supplementary data section). HVSTI (Harvest Index: fraction of aboveground biomass removed in harvest) was identified as the critical parameter responsible for differences in pollutant losses reductions obtained with switchgrass and miscanthus. In this study, HVSTI was defined as 0.9 for switchgrass (SWAT default) and 1.0 for miscanthus (Ng et al., 2010 Trybula et al., 2014). Another SWAT modeling study used HVSTI value of 0.8 for switchgrasss (Baskaran et al., 2010). We recognize that a practical range of HVSTI values for SWAT modeling may become available in the future as forage harvesting management issues pointed out by Trybula et al. (2014) are taken into consideration. Changing HVSTI from 0.9 to 1.0 for switchgrass resulted in lesser pollutant losses reductions. This was because of the fact that $100 \%$ harvest of the aboveground biomass of switchgrass (HVSTI=1) will result in more pollutant losses after the harvest due to lesser or no ground cover compared to the $90 \%$ harvest scenario (HVSTI $=0.9$ ).

By using the new targeting approach, impact of land use changes can be better appraised. Most accurate simulation of land use changes in SWAT is needed in the near future because of the continued widespread use of SWAT. The new simulation approach can be used for all new SWAT model setups as opposed to the SWAT models that has already been setup i.e. their HRUs are already delineated. This is because the spatial marginal land layer has to be processed with the land use layer before HRUs are delineated. The processed land use layer (or the modified LULC) can then be used for the creation of HRUs. In the future, we plan to develop a tool to redistribute delineated HRUs based on the marginal land locations. As a result, the tool can automate this approach identifying marginal land HRUs in existing SWAT projects.

\section{SUMMARY}

A new targeted land use simulation approach was developed to locate marginal land with a correct spatial definition in the SWAT model. A modified LULC layer was prepared and input in SWAT for locating marginal lands in the LRW. Simulations were performed at a daily time step for the period covering 1986 to 2008. Statistical and graphical results for the calibration and validation period, analyzed on a monthly time step for the multi-site, multi-variable, and multi-objective model for output variables indicated that there was a good correspondence between the simulated and measured data. The conventional approach resulted in higher sediment, TP, and TN losses as compared to the new approach. As there was an additional 209 square kilometers of marginal land under the conventional approach due to the model's limitation to exclude non-targeted HRUs, pollutant losses from the additional marginal land explained the differences in the sediment, TP, and TN losses for the conventional and new appraoch. The results indicated that the pollutant losses under new simulation approach would be substantially lower as compared to the conventional modeling approach. Compared to baseline pollutant losses, simulation of switchgrass and miscanthus on marginal lands resulted in $94 \%$ and $78 \%$ decrease in sediment, $96 \%$ and $90 \%$ 
decrease in TP, and $80 \%$ and $67 \%$ decrease in $\mathrm{TN}$, respectively. The differences in pollutant losses reductions were traced to the land cover/plant growth parameters for switchgrass and miscanthus. Based on these results, it can be said that production of switchgrass and miscanthus on marginal lands have the potential to improve water quality (sediment, TP, and TN) compared to baseline row crops produced on LRW. Because of the generic nature of this new targeted land use simulation approach, any user-defined targeted area can be incorporated in SWAT at the HRU level for simulating user-defined crops. Considering the increased application of SWAT model at the HRU level for targeting areas, this new targeted land use simulation approach can prove useful in reporting the most accurate results to the conservation agencies, non-governmental organizations, researchers, etc.

\section{ACKNOWLEDGEMENTS}

The authors thank the Department of Energy and Arkansas Natural Resources Commission for funding this study. Thanks also to Dr. Naresh Pai (Stone Environmental) for his valuable inputs on this project.

\section{REFERENCES}

ADEQ. 2012. Category 5 Waters: Arkansas's Water Quality Limited Waterbodies (streams) - 2012 303(d) list. Little Rock, Ark.: ADEQ. Available at: http://www.adeq.state.ar.us/water/branch_planning/303d/pdfs/draft_2012_303(d)_list.pdf. Accessed 28 Nov. 2015.

Ahmadi, M., M. Arabi, J. C. Ascough, D. G. Fontane, and B. A. Engel. 2014. Toward improved calibration of watershed models: Multisite multiobjective measures of information. Environ. Modelling \& Software 59: 135145.

ANRC. 2012. State of Arkansas Nutrient Reduction Strategy. Little Rock, Ark.: ANRC. Available at: https://static.ark.org/eeuploads/anrc/AR_Nutrient_Reduction_Strategy_101014.pdf. Accessed 28 Nov. 2015.

Arnold, J. G., and P. M. Allen. 1999. Automated methods for estimating flow and ground water recharge from streamflow records. J. American Water Res. Assoc. 35(2): 411 - 423.

Arnold, J., J. Kiniry, R. Srinivasan, J. Williams, E. Haney, and S. Neitsch. 2011. Soil and Water Assessment Tool Input/Output File Documentation, Version 2009, Temple, Texas: USDA Grassland, Soil and Water Research Lab, Blackland Research Center, Texas Agricultural Experiment Station.

Arnold, J., D. Moriasi, P. Gassman, K. Abbaspour, M. White, R. Srinivasan, C. Santhi, R. Harmel, A. van Griensven, and M. Van Liew. 2012. SWAT: Model use, calibration, and validation. Trans. ASABE 55(4): 1491-1508. 
Audubon. 2005. The L’Anguille River Watershed restoration plan. Final Report for Project\# 03-140.

Babcock, B. A., P. Gassman, M. Jha, and C. Kling. 2007. Adoption subsidies and environmental impacts of alternative energy crops. Briefing Paper 07-BP 50. Ames, Iowa: CARD.

Baskaran, L., H. Jager, P. Schweizer, and R. Srinivasan. 2010. Progress toward evaluating the sustainability of switchgrass as a bioenergy crop using the SWAT model. Trans. ASABE 53(5): 1547-1556.

Bekiaris, I., I. Panaopoulos, and M. Mimikou. 2005. Application of the SWAT (Soil and Water Assessment Tool) Model in the Ronnea Catchment of Sweden. Global NEST J. 7(3): 252-257.

Boyle, D. P., H. V. Gupta, and S. Sorooshian. 2000. Toward improved streamflow forecasts: Value of semidistributed modeling. Water Res. Research 37(11): 2749-2759.

Busteed, P. R., D. E. Storm, M. J. White, and S. H. Stoodley. 2009. Using SWAT to target critical source sediment and phosphorus areas in the Wister Lake Basin, USA. Am. J. of Environ. Sci. 5(2): 156-163.

Campbell, J. E., D. B. Lobell, R. C. Genova, and C. B. Field. 2008. The global potential of bioenergy on abandoned agriculture lands. Environ. Sci. Tech. 42(15): 5791-5794.

Cao, W., W. B. Bowden, T. Davie, and A. Fenemor. 2006. Multi-variable and multi-site calibration and validation of SWAT in a large mountainous catchment with high spatial variability. Hydrol. Proc. 20(5): 1057-1073.

CAST. 2007. Land Use Land Cover Fall 2006 (raster). Fayetteville, Ark.: Center for Advanced Spatial Technologies. Available at:

http://www.geostor.arkansas.gov/G6/Home.html?id=31a09ad7c9e178278cf2378c550ee18d. Accessed 1 Nov. 2013.

Chaubey, I., A. S. Cotter, T. A. Costello, and T. S. Soerens. 2005. Effect of DEM data resolution on SWAT output uncertainty. Hydrological Proc. 19(3): 621-628.

Chu, T., A. Shirmohammadi, H. Montas, and A. Sadeghi. 2004. Evaluation of the SWAT model sediment and nutrient components in the piedmont physiographic region of Maryland. Trans. ASABE 47(5): 1523-1538.

Dale, V. H., K. L. Kline, J. Wiens, and J. Fargione. 2010. Biofuels: Implications for Land Use and Biodiversity. Biofuels and Sustainability Reports. Washington, D.C.: Ecological Society of America. 
Donner, S. D., and C. J. Kucharik. 2008. Corn-based ethanol production compromises goal of reducing nitrogen export by the Mississippi River. Proc. Natl. Academy of Sci. 105(11): 4513-4518.

EISA. 2007. One hundred tenth congress of the United States of the America. Washington, DC: Energy Independence and Security Act of 2007. Available at: http://www.gpo.gov/fdsys/pkg/BILLS110hr6enr/pdf/BILLS-110hr6enr.pdf. Accessed 28 Nov. 2015.

EPA. 2012. Renewable Fuel Standard (RFS). Washington, D.C.: Environmental Protection Agency. Available at: http://www.epa.gov/otaq/fuels/renewablefuels/index.htm. Accessed 28 Nov. 2015.

Ercan, M. B., J. L. Goodall, A. M. Castronova, M. Humphrey, and N. Beekwilder. 2014. Calibration of SWAT models using the cloud. Environ. Modelling \& Software 62: 188-196.

ESRI. 2012. Redlands, Cal.: Environmental Systems Research Institute. Available at: http://www.esri.com/. Accessed 28 Nov. 2015.

Feyereisen, G. W., T. C. Strickland, D. D. Bosch, and D. G. Sullivan. 2007. Evaluation of SWAT manual calibration and input parameter sensitivity in the Little River watershed. Trans. ASABE 50(3): 843-855.

Gassman, P. W., M. R. Reyes, C. H. Green, and J. G. Arnold. 2007. The Soil and Water Assessment Tool: Historical development, applications, and future research directions. Trans. ASABE 50(4): 1211-1250.

Geiver, L. 2012. U.S.-India collaboration awarded funding for energy crop work: 15 August 2012. Grand Forks, N.D.: Biomass Magazine. Available at: http://biomassmagazine.com/articles/7945/u-s-india-collaborationawarded-funding-for-energy-crop-work. Accessed 28 Nov. 2015.

Ghebremichael, L., T. Veith, and M. Watzin. 2010. Determination of critical source areas for phosphorus loss: Lake Champlain basin, Vermont. Trans. ASABE 53(5): 1595-1604.

Giri, S., A. P. Nejadhashemi, and S. A. Woznicki. 2012. Evaluation of targeting methods for implementation of best management practices in the Saginaw River Watershed. J. Environ. Mgmt. 103: 24-40.

Gopalakrishnan, G., M. Cristina Negri, and S. W. Snyder. 2011. A Novel Framework to Classify Marginal Land for Sustainable Biomass Feedstock Production. J. Environ. Qual. 40(5): 1593-1600.

Haggard, B., T. Soerens, W. Green, and R. Richards. 2003. Using regression methods to estimate stream phosphorus loads at the Illinois River, Arkansas. Appl. Eng. in Agric. 19(2): 187-196. 
Her, Y., J. Frankenberger, I. Chaubey, and R. Srinivasan. 2015. Threshold effects in HRU definition of the Soil and Water Assessment Tool. Trans. ASABE 58(2): 367-378.

Huang, J. J., X. Lin, J. Wang and H. Wang. 2015. The precipitation driven correlation based mapping method (PCM) for identifying the critical source areas of non-point source pollution. J. Hydrology 524: 100-110.

Kloverpris, J., H. Wenzel, and P. H. Nielsen. 2008. Life cycle inventory modelling of land use induced by crop consumption. Intl. J. Life Cycle Assess. 13(1): 13-21.

Kort, J., M. Collins, and D. Ditsch. 1998. A review of soil erosion potential associated with biomass crops. Biomass and Bioenergy 14(4): 351-359.

Maringanti, C. 2008. Development of a multi-objective optimization tool for the selection and placement of BMPs in a watershed for NPS pollution control. M.S. thesis. Purdue, Ind.: Purdue University, Department of Agricultural and Biological Engineering.

Migliaccio, K. W., and I. Chaubey. 2007. Comment on Cao W, Bowden BW, Davie T, Fenemor A. 2006. Multivariable and multi-site calibration and validation of SWAT in a large mountainous catchment with high spatial variability. Hydrol. Proc. 20 (5): 1057-1073. Hydrol. Proc. 21(23): 3226-3228.

Moriasi, D., J. Arnold, M. Van Liew, R. Bingner, R. Harmel, and T. Veith. 2007. Model evaluation guidelines for systematic quantification of accuracy in watershed simulations. Trans. ASABE 50(3): 885-900.

Niraula, R., L. Kalin, R. Wang and P. Srivastava. 2012. Determining nutrient and sediment critical source areas with SWAT: effect of lumped calibration. Trans. ASABE 55(1): 137-147.

Niraula, R., L. M. Norman, T. Meixner and J. B. Callegary. 2012. Multi-gauge Calibration for modeling the semiarid Santa Cruz Watershed in Arizona-Mexico border area using SWAT. Air, Soil and Water Research 5: 4157.

Ng, T. L., J. W. Eheart, X. Cai, and F. Miguez. 2010. Modeling Miscanthus in the Soil and Water Assessment Tool (SWAT) to Simulate Its Water Quality Effects As a Bioenergy Crop. Environ. Sci. Tech. 44(18): 7138-7144.

NRCS. 2012. National Soil Survey Handbook (NSSH) Part 622. Washington, D.C.: USDA National Resources Conservation Service. Available at: http://archive.is/Rvkz. Accessed 28 Nov. 2015. 
Onusluel, G., and D. Rosbjerg. 2010. Modelling of hydrologic processes and potential response to climate change through the use of a multisite SWAT. Water Environ. J. 24(1): 21-31.

Pai, N., and D. Saraswat. 2011. SWAT2009_LUC: A tool to activate the land use change module in SWAT 2009. Trans. ASABE 54(5): 1649-1658.

Pai, N., and D. Saraswat. 2013. Impact of land use and land cover categorical uncertainty on SWAT hydrologic modeling. Trans. ASABE 56(4): 1387-1397.

Pai, N., D. Saraswat, and M. Daniels. 2011. Identifying priority subwatersheds in the Illinois River Drainage Area in Arkansas watershed using a distributed modeling approach. Trans. ASABE 54(6): 2181-2196.

Pai, N., D. Saraswat, and R. Srinivasan. 2012. Field_SWAT: A tool for mapping SWAT output to field boundaries. Computers and Geosci. 40: 175-184.

Panagopoulos, Y., C. Makropoulos, E. Baltas and M. Mimikou. 2011. SWAT parameterization for the identification of critical diffuse pollution source areas under data limitations. Ecological Modelling 222(19): 3500-3512

Parajuli, P. B. and S. E. Duffy. 2013. Quantifying Hydrologic and Water Quality Responses to Bioenergy Crops in Town Creek Watershed in Mississippi. J. Sustainable Bioenergy Systems 3: 202-208.

Parish, E. S., M. R. Hilliard, L. M. Baskaran, V. H. Dale, N. A. Griffiths, P. J. Mulholland, A. Sorokine, N. A. Thomas, M. E. Downing and R. S. Middleton. 2012. Multimetric spatial optimization of switchgrass plantings across a watershed. Biofuels, Bioproducts and Biorefining 6: 58-72.

Popp, M., and R. Hogan Jr. 2007. Assessment of two alternative switchgrass harvest and transport methods. Farm Foundation Paper No. 48774. St. Louis, Mo.: Biofuels, Food and Feed Tradeoffs, Biofuels, Food and Feed Tradeoffs Conference.

Powers, S. E. 2007. Nutrient loads to surface water from row crop production. Intl. J. Life Cycle Assess. 12(6): 399407.

Rouholahnejad, E., K. C. Abbaspour, M. Vejdani, R. Srinivasan, R. Schulin, and A. Lehmann. 2012. A parallelization framework for calibration of hydrological models. Environ. Modelling \& Software 31: 28-36.

Qi, C., and S. Grunwald. 2005. GIS-based hydrologic modeling in the Sandusky watershed using SWAT. Trans. $A S A B E$ 48(1): 169-180. 
Santhi, C., J. G. Arnold, J. R. Williams, W. A. Dugas, R. Srinivasan, and L. M. Hauck. 2001. Validation of the SWAT model on a large river basin with point and nonpoint sources. J. American Water Res. Assoc. 37(5): 1169-1188.

Saraswat, D., N. Pai, and P. Tacker. 2008. Watershed response modeling for 12-digit Hydrologic Unit Code "HUC" in L’Anguille River Watershed. Project \# 04-121. Pp 44. Little Rock, Ark.: Arkansas Natural Resources Commission.

Sarkar, S., S. A. Miller, J. R. Frederick, and J. F. Chamberlain. 2011. Modeling nitrogen loss from switchgrass agricultural systems. Biomass and Bioenergy 35: 4381-4389.

Seaber, P., F. P. Kapinos, and G. L. Knapp. 1994. Hydrological Unit Maps. USGS water-supply Paper \# 2294. Denver, CO: United States Geological Survey.

Singh, V. P., and D. K. Frevert. 2006. Watershed models. Boca Raton, Fl: Taylor and Francis Group LLC.

Sloboda, M., and D. A. Swayne. 2013. Autocalibration experiments using machine learning and high performance computing. Environ. Modelling \& Software 40: 302-315.

Srinivasan, R., T. Ramanarayanan, J. Arnold, and S. Bednarz. 1998. Large area hydrologic modeling and assessment part II: model development. J. American Water Res. Assoc. 34(1): 91-101.

Srinivasan, R., X. Zhang, and J. Arnold. 2010. SWAT ungauged: hydrological budget and crop yield predictions in the Upper Mississippi River Basin. Trans. ASABE 53(5): 1533-1546.

Strijker, D. 2005. Marginal lands in Europe--causes of decline. Basic Appl. Ecol. 6(2): 99-106.

USDA-NRCS. 2009. Chapter 7: Hydrological Soil Groups. In National Engineering Handbook Part 630.

Washington, D.C.: USDA Natural Resource Conservation Service.

West, C. P., B. C. Grigg, C. A. Guerber, R. Farris, and K. R. Brye. 2011. Poultry litter effects on switchgrass and sorghum biomass yield and macronutrient removal. In ASA, CSSA, and SSSA International Annual Meetings, Abstract No. 62-13. San Antonio, Texas: ASA, CSSA, and SSSA. 
Winchell, M. F., S. Folle, D. Meals, J. Moore, R. Srinivasan and E. A. Howe. 2014. Using SWAT for sub-field identification of phosphorus critical source areas in a saturation excess runoff region. Hydrological Sciences Journal, DOI: 10.1080/02626667.2014.980262

White, K. L., and I. Chaubey. 2005. Sensitivity analysis, calibration, and validation for a multisite and multivariable SWAT model. J. American Water Res. Assoc. 41(5): 1077-1089.

White, M. J., D. E. Storm, P. R. Busteed, S. H. Stoodley, and S. J. Phillips. 2009. Evaluating nonpoint source critical source area contributions at the watershed scale. J. Environ. Qual. 38(4): 1654-1663.

$\underline{\text { Wu, Y., and S. Liu. 2012. Automating calibration, sensitivity and uncertainty analysis of complex models using the }}$

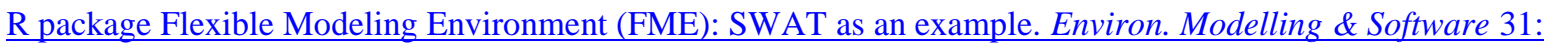
99-109.

Yang, Q., G. A. Benoy, T. L. Chow, J. L. Daigle, C. P. A. Bourque, and F. R. Meng. 2012. Using the Soil and Water Assessment Tool to estimate achievable water quality targets through implementation of beneficial management practices in an agricultural watershed. J. Environ. Qual. 41(1): 64-72.

\section{APPENDIX: SUPPLEMENTARY DATA}

Table A1: Land cover/plant growth parameters for Alamo swichgrass and giant miscanthus.

\begin{tabular}{|l|l|l|}
\hline Parameter* & Switchgrass & Miscanthus \\
\hline BIO_E [(kg/ha)/MJ/m2)] & 47 & 39 \\
\hline HVSTI $[(\mathrm{kg} / \mathrm{ha}) /(\mathrm{kg} / \mathrm{ha})]$ & 0.9 & 1 \\
\hline BLAI $(\mathrm{m} 2 / \mathrm{m} 2)$ & 10 & 11.5 \\
\hline
\end{tabular}




\begin{tabular}{|c|c|c|}
\hline FRGRW1 (fraction) & 0.1 & 0.1 \\
\hline LAIMX1 (fraction) & 0.2 & 0.2 \\
\hline CHTMX (m) & 3 & 4 \\
\hline RDMX (m) & 2.2 & 4 \\
\hline FRGRW2 (fraction) & 0.2 & 0.5 \\
\hline LAIMX2 (fraction) & 0.95 & 0.95 \\
\hline DLAI (heat units/heat units) & 0.7 & 0.85 \\
\hline T_OPT (C) & 25 & 30 \\
\hline T_BASE (C) & 12 & 10 \\
\hline CNYLD (kg N/kg seed) & 0.016 & 0.005 \\
\hline CPYLD (kg P/ kg seed) & 0.0022 & 0.00063 \\
\hline BN1 (kg N/kg biomass) & 0.035 & 0.0304 \\
\hline BN2 (kg N/kg biomass) & 0.015 & 0.0074 \\
\hline BN3 (kg N/kg biomass) & 0.0038 & 0.0057 \\
\hline BP1 (kg P/kg biomass) & 0.0014 & 0.00337 \\
\hline BP2 (kg P/kg biomass) & 0.001 & 0.00104 \\
\hline BP3 (kg P/kg biomass) & 0.0007 & 0.00082 \\
\hline WSYF [(kg/ha)/(kg/ha)] & 0.9 & 1 \\
\hline USLE_C & 0.003 & 0.003 \\
\hline GSI (m/s) & 0.005 & 0.005 \\
\hline VPDFR (kPa) & 4 & 4 \\
\hline FRGMAX (fraction) & 0.75 & 0.75 \\
\hline WAVP (rate) & 8.5 & 7.2 \\
\hline CO2HI (uL/L) & 660 & 660 \\
\hline BIOEHI (ratio) & 54 & 54 \\
\hline RSDCO_PL (fraction) & 0.05 & 0.05 \\
\hline ALAI_MIN (m2/m2) & 0 & 0 \\
\hline BIO_LEAF (fraction) & 0 & 0 \\
\hline MAT_YRS (years) & 0 & 0 \\
\hline BMX_TREES (tons/ha) & 0 & 0 \\
\hline EXT_COEF & 0.33 & 0.65 \\
\hline BM_DIEOFF & 0.1 & 0.1 \\
\hline
\end{tabular}

*Details about the parameters can be obtained from the SWAT Input/Output documentation available at:

http://swatmodel.tamu.edu/media/19754/swat-io-2009.pdf 

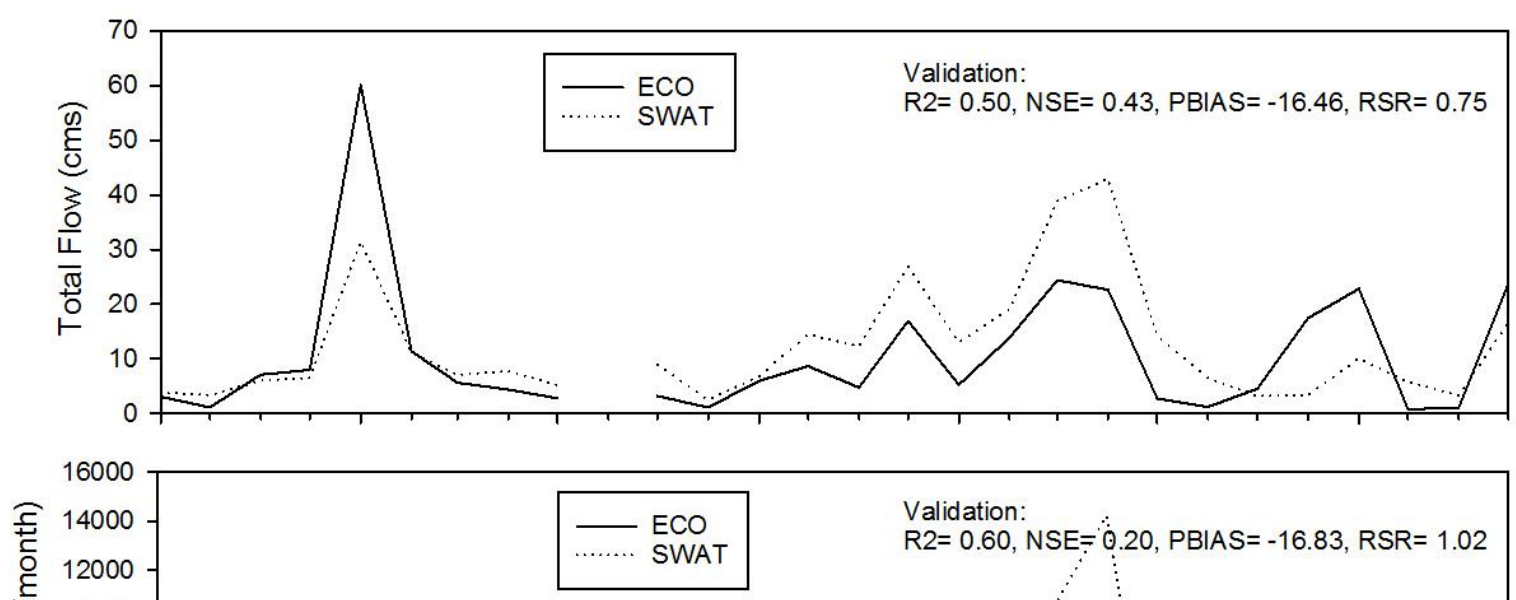

के 10000
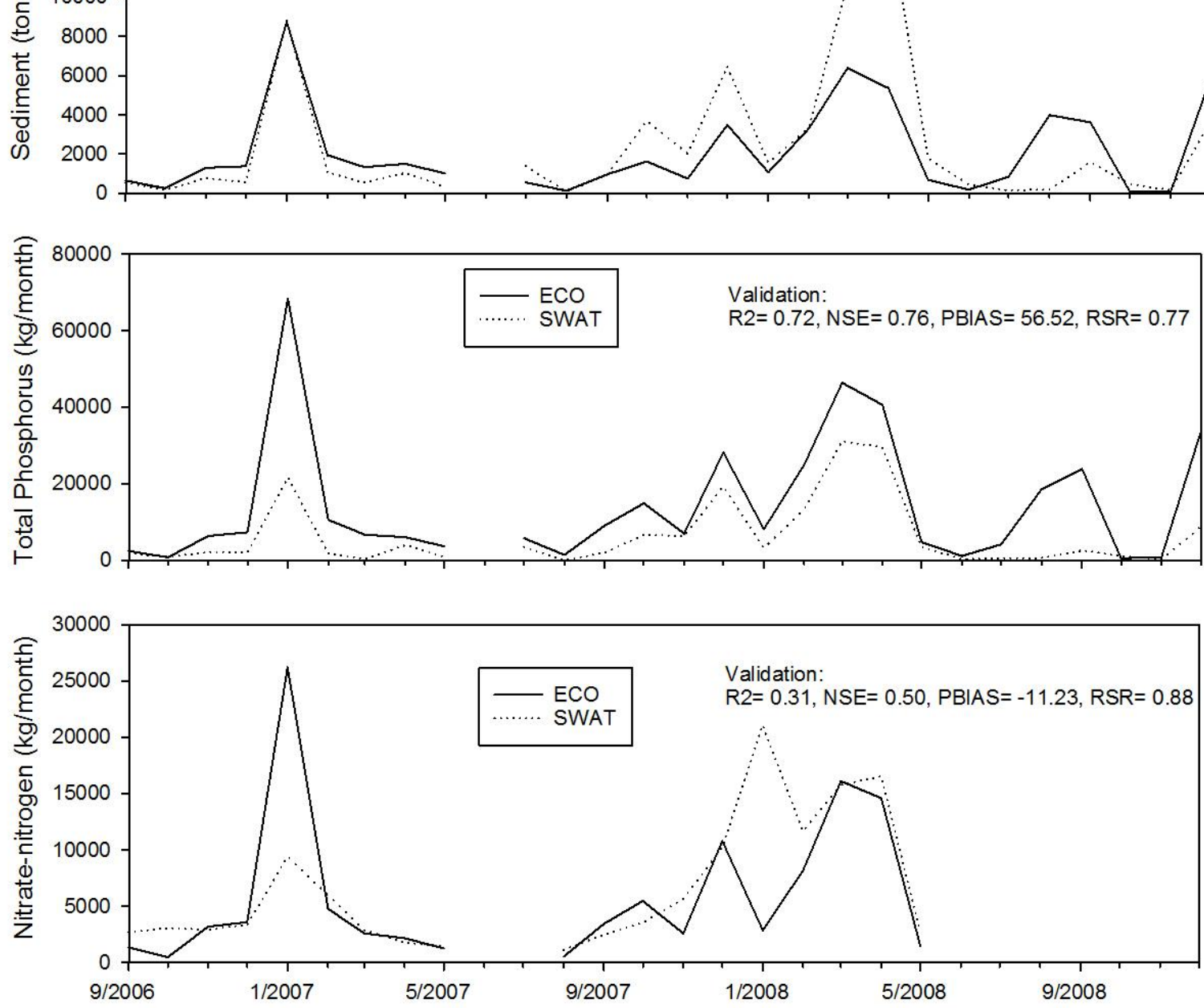

Fig. A1. Time series plots (monthly: 1990-2008) for total flow, sediments, total phosphorus, and nitrate-nitrogen validation at Vannadale. 
Table A2: Percentage reductions in sediment, total phosphorus, and total nitrogen from baseline when land cover/plant growth parameters for Alamo switchgrass were replaced with that for giant miscanthus one at a time.

\begin{tabular}{|c|c|c|c|}
\hline Parameter $\dagger$ & Sediment & Total Phosphorus & Total Nitrogen \\
\hline HVSTI & -64 & -86 & -57 \\
\hline BIOE & -93 & -96 & -79 \\
\hline BLAI & -94 & -96 & -80 \\
\hline CHTMX & -94 & -96 & -80 \\
\hline RDMX & -94 & -96 & -80 \\
\hline FRGRW2 & -95 & -97 & -81 \\
\hline DLAI & -95 & -97 & -81 \\
\hline T_OPT & -94 & -96 & -80 \\
\hline T_BASE & -96 & -97 & -82 \\
\hline CNYLD & -94 & -96 & -80 \\
\hline CPYLD & -94 & -96 & -80 \\
\hline BN1 & -94 & -96 & -80 \\
\hline $\mathrm{BN} 2$ & -96 & -97 & -81 \\
\hline BN3 & -93 & -96 & -79 \\
\hline BP1 & -93 & -96 & -78 \\
\hline BP2 & -94 & -96 & -80 \\
\hline BP3 & -94 & -96 & -80 \\
\hline WSYF & -94 & -96 & -80 \\
\hline WAVP & -94 & -96 & -80 \\
\hline EXT_COEF & -96 & -97 & -83 \\
\hline
\end{tabular}

$\dagger$ Details about the parameters can be obtained from the SWAT Input/Output documentation available at: http://swatmodel.tamu.edu/media/19754/swat-io-2009.pdf 